Research article

Open Access

\title{
Frequent loss of endothelin-3 (EDN3) expression due to epigenetic inactivation in human breast cancer
}

\author{
Frank Wiesmann ${ }^{1 *}$, Jürgen Veeck ${ }^{2 *}$, Oliver Galm³${ }^{3}$, Arndt Hartmann ${ }^{4}$, Manel Esteller ${ }^{2}$, \\ Ruth Knüchel ${ }^{1}$ and Edgar Dahl1
}

\author{
${ }^{1}$ Molecular Oncology Group, Institute of Pathology, University Hospital of the RWTH Aachen, Pauwelsstrasse 30, D-52074 Aachen, Germany \\ ${ }^{2}$ Cancer Epigenetics Group, Cancer Epigenetics and Biology Program (PEBC), Bellvitge Institute for Biomedical Research (ICO-IDIBELL), Av. Gran \\ Via de L'Hospitalet 199-203, E-08907 Barcelona, Spain \\ 3Department of Internal Medicine IV (Haematology/Oncology), University Hospital of the RWTH Aachen, Pauwelsstrasse 30, 52074 D-Aachen, \\ Germany \\ ${ }^{4}$ Department of Pathology, University of Erlangen, Krankenhausstrasse 12, D-91054 Erlangen, Germany \\ ${ }^{*}$ Contributed equally
}

Corresponding author: Edgar Dahl, edahl@ukaachen.de

Received: 26 Mar 2009 Revisions requested: 27 Apr 2009 Revisions received: 10 Jun 2009 Accepted: 15 Jun 2009 Published: 15 Jun 2009

Breast Cancer Research 2009, 11:R34 (doi:10.1186/bcr2319)

This article is online at: http://breast-cancer-research.com/content/11/3/R34

(c) 2009 Wiesmann et al.; licensee BioMed Central Ltd.

This is an open access article distributed under the terms of the Creative Commons Attribution License (http://creativecommons.org/licenses/by/2.0), which permits unrestricted use, distribution, and reproduction in any medium, provided the original work is properly cited.

\begin{abstract}
Introduction Endothelin (EDN) signalling plays a crucial role in cell differentiation, proliferation and migration processes. There is compelling evidence that altered EDN signalling is involved in carcinogenesis by modulating cell survival and promoting invasiveness. To date, most reports have focused on the oncogenic potential of EDN1 and EDN2, both of which are overexpressed in various tumour entities. Here, we aimed at a first comprehensive analysis on EDN3 expression and its implication in human breast cancer.
\end{abstract}

Methods EDN3 mRNA expression was assessed by Northern blotting in normal human tissues $(n=9)$ as well as in matched pairs of normal and tumourous tissues from breast specimens (n = 50). EDN3 mRNA expression in breast cancer was further validated by real-time polymerase chain reaction (PCR) $(n=77)$. A tissue microarray was used to study EDN3 protein expression in breast carcinoma $(n=150)$ and normal breast epithelium ( $n$ $=44)$. EDN3 promoter methylation was analysed by methylation-specific PCR in breast cell lines $(n=6)$ before and after demethylating treatment, normal breast tissues $(n=17)$ and primary breast carcinomas $(n=128)$. EDN3 expression and methylation data were statistically correlated with clinical patient characteristics and patient outcome.
Results Loss of EDN3 mRNA expression in breast cancer, as initially detected by array-based expression profiling, could be confirmed by Northern blot analysis ( $>2$-fold loss in $96 \%$ ) and real-time PCR ( $>2$-fold loss in 78\%). Attenuated EDN3 expression in breast carcinoma was also evident at the protein level $(45 \%)$ in association with adverse patient outcome in univariate $(P=0.022)$ and multivariate (hazard ratio $2.0 ; P=$ 0.025 ) analyses. Hypermethylation of the EDN3 promoter could be identified as the predominant mechanism leading to gene silencing. Reversion of the epigenetic lock by 5-aza-2'deoxycytidine and trichostatin A resulted in EDN3 mRNA reexpression in vitro. Furthermore, EDN3 promoter hypermethylation was detected in $70 \%$ of primary breast carcinomas with significant association to loss of EDN3 mRNA expression $(P=0.005)$, whilst normal matched breast tissues revealed no EDN3 promoter methylation.

Conclusions EDN3 is a frequent target of epigenetic inactivation in human breast cancer, potentially contributing to imbalanced EDN signalling commonly found in this disease. The clinical implication supports the view that EDN3, in contrast to EDN1 and EDN2, may act as natural tumour suppressor in the human mammary gland.

bp: base pair(s); Cl: confidence interval; CPA: cancer profiling array; CpG: cytosine-phosphate-guanine dinucleotide; CSS: breast cancer-specific survival; $\mathrm{C}_{\mathrm{T}}$ : cycle threshold; DAC: 5-aza-2'-deoxycytidine; DFS: disease-free survival; DNMT: DNA methyltransferase; EDN: endothelin; EDNR: endothelin receptor; ET-axis: endothelin axis; FC2: fold change of greater than 2; FFPE: formalin-fixed paraffin-embedded; GAPDH: glyceraldehyde3-phosphate-dehydrogenase; HDAC: histone acetyltransferase; IHC: immunohistochemistry; IRS: immunoreactivity score; MSP: methylation-specific polymerase chain reaction; MTN: multiple-tissue Northern (blot); PCR: polymerase chain reaction; SD: standard deviation; TMA: tissue microarray; TSA: trichostatin A. 


\section{Introduction}

Endothelins (EDNs) are widely expressed cytokines in a variety of human tissues, including brain, skeletal muscle, pancreas, small intestine, testis and colon [1]. They constitute a family of small, vasoactive, 21-amino acid peptides referred to as EDN1, EDN2 and EDN3 [2]. EDNs are synthesised as large precursor proteins that are post-translationally cleaved to the biologically active 21-amino acid form [3]. They are involved in fundamental cellular networks like cell proliferation, migration and differentiation processes $[4,5]$ by interacting with their corresponding cell surface-bound EDN-A (EDNRA) and EDN$B$ (EDNRB) receptors in an autocrine and also a paracrine manner [6-8]. A balanced regulation of this EDNRA/EDNRB interplay - also referred to as the endothelin axis (ET-axis)- is essential for, for example, homing processes to tissue destinations, where cells differentiate into numerous lineages such as the peripheral nervous system, structural and connective tissue components, cardiac cells or pigment-producing melanocytes [9].

There is now compelling evidence that imbalanced regulation of the ET-axis is implicated in human carcinogenesis, tumour progression and neo-angiogenesis [8,10-12]. During malignant cell transformation, the basic tissue architecture, which is maintained by basement membrane delineation, becomes disrupted [8]. This indicates the presence of crucial mediators that trigger the exchange of growth factors between the participating cells at the tumour invasion field. Essentially, such growth factor release is thought to enhance invasiveness, stimulate cell migration and promote neo-vascularisation [8]. Multiple signal transduction pathways are affected downstream from EDNRA/B. In the case of interaction of EDNs with EDNRA, a pertussis toxin-insensitive $G$ protein becomes activated and promotes stimulation of phospholipase $\mathrm{C}$, resulting in the transactivation of the mitogen-activated protein kinase pathway [13]. Second, EDN1 and EDN2 binding to EDNRA can activate p125 focal adhesion kinase and paxillin, both of which have been associated with increased tumour cell invasion. Moreover, EDNs are able to transduce the activation of anti-apoptotic signals through phosphatidylinositol-3-kinase and to stimulate neo-angiogenesis through vascular endothelial growth factor signalling [14]. These multiple ET-axis pathway implications may explain its various impairments of normal cellular integrity in case of an aberrant shift from balanced to imbalanced EDN signalling.

Previously, EDN1 and EDN2 were found to be commonly overexpressed in a broad range of human tumour entities $[8,11,12]$. So far, most reports have focused on the role of EDN1 binding to EDNRA and its effects on tumour growth and neo-angiogenesis $[8,11,13,15]$. A role similar to that of EDN1 has been described for EDN2 in human breast cancer. Increased expression of EDN1 and EDN2, but not of EDN3, induced chemotaxis of breast cancer cells and increased tumour cell invasion through the basement membrane [4], although conflicting results have been reported by others [16]. In line with this, previous reports described a compensatory effect of EDN3 by negatively modulating the effects transduced by EDN1 [17] and demonstrated that downregulation of EDN3 is associated with upregulation of EDN1 in human tissues [18].

However, a comprehensive analysis of EDN3 expression in normal and cancerous breast tissues and its potential implication in human breast cancer has not been published so far. In our study, we investigated for the first time EDN3 mRNA and protein expression in a large number of primary breast tissues and breast cell lines. Furthermore, we identified the molecular mechanism by which EDN3 expression is deregulated in breast carcinomas.

\section{Materials and methods}

\section{Cryo-conserved clinical patient material}

Cryo-conserved clinical samples were obtained from breast cancer patients treated by primary surgery at the University Hospitals of Aachen, Düsseldorf and Regensburg. Patients receiving neo-adjuvant chemotherapy and patients with recurrent breast cancer were excluded. Resected tissue was snapfrozen in liquid nitrogen immediately after surgery. Only samples containing more than $70 \%$ of tumourous cells in haematoxylin/eosin-stained control sections were further processed $(n=128)$. For 17 samples, macroscopically normal breast tissues containing at least $30 \%$ of epithelial cells were available. In all cases, two board-certified pathologists agreed on the diagnosis of breast cancer. Tumour histology was determined according to the criteria of the World Health Organization (2003), whereas disease stage was assessed according to the UICC (Union Internationale contre le Cancer) [19]. Tumours were graded according to Bloom and Richardson, as modified by Elston and Ellis [20]. All patients gave informed consent for retention and analysis of their tissue for research purposes, and the institutional review boards of the participating centres approved the study. For 98 patients, follow-up data were available with a median time of 63 months (range 1 to 124 months). Patient characteristics of this cohort are summarised in Table 1.

\section{Formalin-fixed paraffin-embedded clinical patient material}

A tissue microarray (TMA) was created as described previously by Bubendorf and colleagues [21]. The formalin-fixed paraffin-embedded (FFPE) tissue sections were obtained from the archive of the Institute of Pathology, University of Regensburg, Germany. In all cases, two board-certified pathologists agreed on the diagnosis of breast cancer. Patients receiving neo-adjuvant chemotherapy and patients with recurrent breast cancer were excluded. All patients gave informed consent for retention and analysis of their tissues for research purposes, and the institutional review board of the participating centre approved the study. The TMA consisted of 150 primary 
Table 1

\begin{tabular}{|c|c|c|}
\hline Variables & Numbera & Percentage \\
\hline \multicolumn{3}{|l|}{ Clinicopathological factors } \\
\hline \multicolumn{3}{|l|}{ Age at diagnosis ${ }^{b}$} \\
\hline$<58$ years & 64 & 50.0 \\
\hline$\geq 58$ years & 64 & 50.0 \\
\hline \multicolumn{3}{|l|}{ Tumour size ${ }^{c}$} \\
\hline pT1 & 44 & 34.4 \\
\hline pT2 & 55 & 43.0 \\
\hline рТ3 & 6 & 4.7 \\
\hline pT4 & 11 & 8.6 \\
\hline pTx & 12 & 9.4 \\
\hline \multicolumn{3}{|l|}{ Lymph node status ${ }^{c}$} \\
\hline pNO & 57 & 44.5 \\
\hline $\mathrm{pN} 1-3$ & 51 & 39.8 \\
\hline $\mathrm{pNx}$ & 20 & 15.6 \\
\hline \multicolumn{3}{|l|}{ Histological grade } \\
\hline G1 & 10 & 7.8 \\
\hline G2 & 58 & 45.3 \\
\hline G3 & 49 & 38.3 \\
\hline NA & 11 & 8.6 \\
\hline \multicolumn{3}{|l|}{ Histological type } \\
\hline Ductal & 103 & 80.5 \\
\hline Lobular & 15 & 11.7 \\
\hline Other & 6 & 4.7 \\
\hline NA & 4 & 3.1 \\
\hline \multicolumn{3}{|l|}{ Immunohistochemistry } \\
\hline \multicolumn{3}{|l|}{ Oestrogen receptor } \\
\hline Negative $\left(I_{R S} d \leq 2\right)$ & 33 & 25.8 \\
\hline Positive (IRS > 2) & 85 & 66.4 \\
\hline NA & 10 & 7.8 \\
\hline \multicolumn{3}{|l|}{ Progesterone receptor } \\
\hline Negative (IRSd $\leq 2)$ & 33 & 25.8 \\
\hline Positive (IRS > 2) & 85 & 66.4 \\
\hline NA & 10 & 7.8 \\
\hline
\end{tabular}

Due to rounding, percentages may not sum to 100 . aOnly female patients with primary invasive breast cancer were included. bMedian 58 years, range 28 to 87 years. cAccording to the UICC (Union Internationale contre le Cancer): TNM Classification of Malignant Tumours [19].dImmunoreactivity score (IRS) according to Remmele and Stegner [24]. NA, information not available. tumours from malignant breast tissue and 44 normal breast specimens. Follow-up data were available for 146 patients with a median time of 77 months (range 1 to 148 months). Detailed tumour characteristics of this cohort are listed in Table 2.

\section{Breast cell lines}

The non-cancerous breast cell lines MCF10A and MCF12A as well as the cancerous breast cell lines MCF7, SKBR3, MDAMB231 and BT20 were obtained from the American Type Culture Collection (Manassas, VA, USA) and cultured as recommended by the vendor.

\section{Northern blot expression analysis}

Expression of EDN3 mRNA in various human tissues was tested using the commercial multiple-tissue Northern (MTN) blots I and II (Clontech, Heidelberg, Germany), containing 2 $\mu \mathrm{g}$ of poly $\mathrm{A}^{+}$RNA per lane from 16 different human tissues (that is, blot I: heart, whole brain, placenta, lung, liver, skeletal muscle, kidney and pancreas; blot II: spleen, thymus, prostate, testis, ovary, small intestine, colon [no mucosa] and peripheral blood lymphocytes). Hybridisation was performed using $25 \mathrm{ng}$ of an EDN3-specific 722-base pair (bp) polymerase chain reaction (PCR) product derived from (GenBank accession number NM_000114.2) (position: 968 to 1,707), which was verified by sequence analysis. ${ }^{32} \mathrm{P}$-labelling of the DNA probe was achieved using the Megaprime DNA Labeling System (Amersham Biosciences, now part of GE Healthcare, Little Chalfont, Buckinghamshire, UK), and hybridisation was performed in accordance with the recommendation the manufacturer. The cancer profiling array (CPA) I (Clontech) is a matched tumour/normal expression array consisting of cDNA synthesised from 50 breast carcinomas, 50 normal breast tissues and 3 breast cancer lymph node metastasis specimens. Hybridisation was performed in accordance with the recommendations the manufacturer as described above for the MTN blots. Hybridisation signals of both, MTN blots and the CPA, were evaluated by use of a STORM-860 phosphoimager (Molecular Dynamics, now part of GE Healthcare). Intensity ratios were calculated after normalising signals against the background.

\section{Nucleic acid extraction}

Frozen tissue samples and cell line pellets were dissolved in lysis buffer for subsequent DNA isolation using the QIAmp DNA Mini kit (Qiagen, Hilden, Germany) or for total RNA isolation by using TRIzol reagent (Invitrogen Corporation, Carlsbad, CA, USA) in accordance with the protocol supplied by the manufacturers.

\section{Reverse transcription of RNA}

Of the extracted total RNA, $1 \mu \mathrm{g}$ was reverse-transcribed using the Reverse Transcription System (Promega Corporation, Madison, WI, USA) by applying a mix of oligo-dT and $\operatorname{pdN}_{(6)}$-hexamer primers (1:2). The obtained cDNA was diluted 
Table 2

\begin{tabular}{|c|c|c|}
\hline Variables & Numbera & Percentage \\
\hline \multicolumn{3}{|c|}{ Clinicopathological factors } \\
\hline \multicolumn{3}{|c|}{ Age at diagnosis ${ }^{b}$} \\
\hline$\leq 59$ years & 83 & 55.3 \\
\hline$>59$ years & 67 & 44.7 \\
\hline \multicolumn{3}{|l|}{ Tumour size ${ }^{c}$} \\
\hline pT1 & 48 & 32.0 \\
\hline pT2 & 71 & 47.3 \\
\hline рT3 & 9 & 6.0 \\
\hline pT4 & 20 & 13.3 \\
\hline pTx & 2 & 1.3 \\
\hline \multicolumn{3}{|c|}{ Lymph node status ${ }^{c}$} \\
\hline pNO & 67 & 44.7 \\
\hline pN1 & 35 & 23.3 \\
\hline pN2 & 25 & 16.7 \\
\hline $\mathrm{pN} 3$ & 20 & 13.3 \\
\hline $\mathrm{pNx}$ & 3 & 2.0 \\
\hline \multicolumn{3}{|c|}{ Histological grade } \\
\hline G1 & 13 & 8.7 \\
\hline G2 & 70 & 46.7 \\
\hline G3 & 66 & 44.0 \\
\hline NA & 1 & 0.7 \\
\hline \multicolumn{3}{|c|}{ Histological type } \\
\hline Ductal & 122 & 81.3 \\
\hline Lobular & 12 & 18.0 \\
\hline Other & 16 & 10.7 \\
\hline \multicolumn{3}{|l|}{ Tumour focality } \\
\hline Unifocal & 130 & 86.7 \\
\hline Multifocal & 19 & 12.7 \\
\hline NA & 1 & 0.7 \\
\hline
\end{tabular}

\begin{tabular}{|c|c|c|}
\hline \multicolumn{3}{|l|}{ Immunohistochemistry } \\
\hline \multicolumn{3}{|l|}{ Oestrogen receptor } \\
\hline Negative (IRS $\mathbf{d} \leq 2)$ & 38 & 25.3 \\
\hline Positive (IRS > 2) & 83 & 55.3 \\
\hline NA & 29 & 19.3 \\
\hline \multicolumn{3}{|l|}{ Progesterone receptor } \\
\hline Negative (IRSd $\leq 2)$ & 85 & 56.7 \\
\hline Positive (IRS > 2) & 40 & 26.7 \\
\hline NA & 25 & 16.7 \\
\hline \multicolumn{3}{|l|}{ Her2 status } \\
\hline Negative (DAKO score $0 ; 1+$ ) & 105 & 70.0 \\
\hline Positive (DAKO score $2+; 3+$ ) & 23 & 15.3 \\
\hline NA & 22 & 14.7 \\
\hline
\end{tabular}

Due to rounding, percentages may not sum to 100 . anly female patients with primary invasive breast cancer were included. bMedian 59 years, range 29 to 82 years. ${ }^{~ A c c o r d i n g ~ t o ~ t h e ~ U I C C ~(U n i o n ~}$ Internationale contre le Cancer): TNM Classification of Malignant Tumours [19]. dImmunoreactivity score (IRS) according to Remmele and Stegner [24]. NA, information not available.
(20 $\mathrm{ng} / \mu \mathrm{L}$ ) and test-amplified using intron-spanning primers for glyceraldehyde-3-phosphate-dehydrogenase (GAPDH). Primer sequences are provided in Table 3. PCRs were initiated as 'Hot Start' PCR at $95^{\circ} \mathrm{C}$ for 5 minutes and a hold at $80^{\circ} \mathrm{C}$ before the addition of 1 unit of GoTaq DNA polymerase (Promega Corporation). Cycle conditions were $95^{\circ} \mathrm{C}$ for 5 minutes, 35 cycles of $95^{\circ} \mathrm{C}$ for 1 minute, $60^{\circ} \mathrm{C}$ for 1 minute, $72^{\circ} \mathrm{C}$ for 1 minute and a final extension at $72^{\circ} \mathrm{C}$ for 10 minutes. PCR analyses were carried out in a PTC-200 cycler (Bio-Rad Laboratories, Inc., formerly MJ Research, Hercules, CA, USA). Amplificates were evaluated under ultraviolet light after $2 \%$ agarose gel electrophoresis containing ethidium bromide. Only samples yielding a specific 510-bp amplificate were further subjected to real-time PCR.

\section{Semi-quantitative real-time polymerase chain reaction}

The Roche LightCycler system was used for semi-quantitative light cycler analysis in combination with the LightCycler DNA Master SYBR Green I Kit (Roche, Mannheim, Germany) as previously described [22]. Gene expression was quantified by the comparative cycle threshold $\left(\mathrm{C}_{\mathrm{T}}\right)$ method, normalising $\mathrm{C}_{\mathrm{T}}$ values to the housekeeping gene $G A P D H$ and calculating relative expression values [23]. A commercially available normal breast cDNA pool (Clontech) was used as a breast reference standard. Primer sequences are listed in Table 3.

\section{Immunohistochemistry}

Paraffin sections of $2 \mu \mathrm{m}$ were deparaffinised in xylene followed by rehydration in a decreasing ethanol series. Antigen retrieval was performed by pre-treatment in boiling citrate buffer ( $\mathrm{pH} \mathrm{6.0)}$ in a microwave oven for 30 minutes (200 W). Immunohistochemistry (IHC) was performed using an NEXES Immuno Stainer (Ventana Medical Systems, Inc., Tucson, AZ, USA) in accordance with the specifications of the manufacturer. A goat polyclonal EDN3-specific antibody (sc-21628; Santa Cruz Biotechnology, Inc., Santa Cruz, CA, USA) was used in a 1:150 dilution by using the ChemMate Envision Kit (DAKO, Hamburg, Germany). Counterstaining was performed by using Mayer's haematoxylin. The incubation with primary antibodies was omitted in negative controls. All analysed samples were stained without the knowledge of histopathological data. Cytoplasmic protein staining was semi-quantitatively scored by an experienced breast pathologist according to the well-established scoring system developed by Remmele and Stegner [24]. To verify staining specificity, the primary antibody was incubated with a 200 molar excess of blocking peptide (sc-21628 P; Santa Cruz Biotechnology, Inc.) for 2 hours prior to its application on test samples.

\section{CpG island prediction}

$E D N 1, E D N 2$ and $E D N 3$ genomic nucleotide sequences were taken from the Ensembl database and analysed for promoter CpG (cytosine-phosphate-guanine dinucleotide) islands in accordance with the method of $\mathrm{Li}$ and Dahiya [25]. A fragment of $2 \mathrm{~kb}$ in size, beginning $1 \mathrm{~kb} 5$ '-upstream from the 
Table 3

\begin{tabular}{|c|c|c|c|c|}
\hline & Sequence $\left(5^{\prime} \leftrightarrow 3^{\prime}\right)$ & $\mathrm{TA},{ }^{\circ} \mathrm{C}$ & Cycles & Product, base pairs \\
\hline \multicolumn{5}{|l|}{ RT-PCR } \\
\hline \multicolumn{5}{|l|}{ GAPDH } \\
\hline & Forward: TGGTCACCAGGGCTGCTT & 60 & 35 & 510 \\
\hline & Reverse: GTCTTCTGGGTGGCAGTGAT & & & \\
\hline \multicolumn{5}{|c|}{ Real-time PCR } \\
\hline \multicolumn{5}{|l|}{ GAPDH } \\
\hline & Forward: GAAGGTGAAGGTCGGAGTCA & 58 & 40 & 108 \\
\hline & Reverse: TGGACTCCACGACGTACTCA & & & \\
\hline \multicolumn{5}{|l|}{ EDN1 } \\
\hline & Forward: GCTCGTCCCTGATGGATAAA & 58 & 40 & 216 \\
\hline & Reverse: TTCCTGCTTGGCAAAAATTC & & & \\
\hline \multicolumn{5}{|l|}{ EDN2 } \\
\hline & Forward: TTGGACATCATCTGGGTGAA & 58 & 40 & 229 \\
\hline & Reverse: CTGTAGTGGCCСCTGTCTTG & & & \\
\hline \multicolumn{5}{|l|}{ EDN3 } \\
\hline & Forward: ATTGCCACCTGGACATCATT & 58 & 40 & 179 \\
\hline & Reverse: GCAGGCCTTGTCATATCTCC & & & \\
\hline \multicolumn{5}{|c|}{ Methylation-specific PCR } \\
\hline \multicolumn{5}{|l|}{ EDN3-U } \\
\hline & Forward: TTTGGGAGGTGATTTTTAGTGTGTTT & 60 & 35 & 144 \\
\hline & Reverse: ACCСАТСССТАСАCAАAАCTAАCCA & & & \\
\hline \multicolumn{5}{|l|}{ EDN3-M } \\
\hline & Forward: TGGGAGGCGATTTTTAGTGCGTTC & 60 & 35 & 140 \\
\hline & Reverse: CCATCCCTACGCGAAACTAACCG & & & \\
\hline
\end{tabular}

EDN, endothelin; EDN3-M, endothelin-3 methylated; EDN3-U, endothelin-3 unmethylated; GAPDH, glyceraldehyde-3-phosphate-dehydrogenase; PCR, polymerase chain reaction; RT-PCR, reverse transcription-polymerase chain reaction; TA, annealing temperature.

annotated transcription start site (TSS) and ending $1 \mathrm{~kb} 3^{\prime}-$ downstream, was analysed by applying the following criteria: island size of greater than $200 \mathrm{bp}$, guanine/cytosine content of greater than $60 \%$ and observed/expected $\mathrm{CpG}$ ratio of greater than 0.6 .

\section{Bisulphite modification and methylation-specific polymerase chain reaction}

Of the genomic DNA, $1 \mu \mathrm{g}$ was bisulphite-modified using the EZ DNA Methylation Kit (Zymo Research Corporation, Orange, CA, USA) and eluted in $20 \mu \mathrm{L}$ of Tris buffer $(10 \mathrm{mM})$. Methylation-specific PCR (MSP) was performed in accordance with the method of Herman and colleagues [26]. One microlitre of bisulphite-treated DNA was amplified using MSP primers that specifically recognise either the unmethylated or methylated EDN3 promoter sequence after bisulphite conver- sion (Table 3). To achieve high accuracy, each primer was designed to cover three CpG sites of template DNA. Commercially available universal poly-methylated DNA and unmethylated DNA (EpiTect Control DNA; Qiagen) were used as positive controls for methylated and unmethylated EDN3 sequences, respectively. MSP products were visualised under ultraviolet light after 3\% low-range ultra agarose gel electrophoresis containing ethidium bromide (Bio-Rad Laboratories, Inc.). Promoter methylation status was interpreted in a binary qualitative fashion.

\section{In vitro demethylating treatment}

Cells were seeded at a density of $3 \times 10^{4}$ cells $/ \mathrm{cm}^{2}$ in a sixwell plate. The demethylation agent 5-aza-2'-deoxycytidine (DAC) (Sigma-Aldrich, Deisenheim, Germany) was added to a final concentration of $1 \mu \mathrm{M}$ in fresh medium at days 1,2 and 3 
after seeding. Additionally, cells were exposed to $300 \mathrm{nM}$ trichostatin A (TSA) (Sigma-Aldrich) on day 3 for 24 hours. Control cells without DAC/TSA were supplied with fresh medium on days 1, 2 and 3. DNA and RNA were extracted on day 4 as mentioned above.

\section{Statistical evaluations}

SPSS version 14.0 (SPSS Inc., Chicago, IL, USA) was used for statistical analyses. All tests were performed two-tailed, and $P$ values of below 0.05 were considered statistically significant. The non-parametric Mann-Whitney $U$ test and the Student $t$ test (paired and unpaired) were used to compare expression results between cancer tissues and normal tissues or between EDN3 mRNA expression and EDN3 methylation status. Contingency table analysis and Fisher exact tests were used to study the statistical association between clinicopathological factors and EDN3 protein expression or EDN3 promoter methylation status. Survival curves comparing patients with or without any of the factors were calculated using the Kaplan-Meier method, with significance evaluated by log-rank statistics. Breast cancer-specific survival (CSS) was measured from the day of surgery until tumour-related death and was censored for patients alive at last contact or in case of death unrelated to the tumour. Disease-free survival (DFS) was measured from surgery until disease relapse and censored for patients alive without evidence of relapse at the last follow-up. For EDN3 protein expression, a multivariate Cox proportional hazard model was employed to assess the relative risks on patient CSS and to test for independent prognostic relevance of clinical/investigational factors. Only patients for whom the status of all selected variables was known were included in the proportional hazard model $(n=121)$. The limit for reverse-selection procedures was $P=0.2$. The proportionality assumption for all variables was assessed with log-negative-log survival distribution functions. For analyses, the following variables were categorised into binary values: smallsized (pT1) versus large-sized (pT2 to pT4), node-negative (pNo) versus node-positive ( $\mathrm{pN} 1$ to $\mathrm{pN} 3$ ) and low-grade (G1 and $\mathrm{G} 2$ ) versus high-grade (G3) tumours.

\section{Results EDN3 mRNA is differentially expressed in human breast cancer}

As previously reported, we performed in silico Northern blot analysis and RNA array-based expression profiling to identify novel candidate genes differentially expressed in human breast cancer $[27,28]$. In the latter approach, EDN3 was detected as one of the most frequently downregulated genes, showing substantial expression loss in 63\% of breast carcinomas (data not shown). Therefore, we started a detailed analysis on EDN3 expression and its potential implication in human breast cancer.

An initial Northern blot analysis of normal human tissues demonstrates that EDN3 mRNA is abundantly expressed in a vari- ety of non-malignant tissues, including pancreas, spleen, prostate, testis, small intestine and colon, with two major mRNA transcripts of 2.4 and $2.7 \mathrm{~kb}$ in size (Figure 1a). A breast cancer dot blot cDNA array was then hybridised with the same EDN3-specific probe. This showed a clear loss of EDN3 mRNA expression, as defined by a fold change (tumour versus normal) of greater than 2 (FC2), in $96 \%$ (48 of 50) of the analysed breast carcinoma samples and also in all three corresponding lymph node metastases $(P<0.001)$ (Figure $1 \mathrm{~b}, \mathrm{c})$. To confirm this result, EDN3 mRNA expression was also assessed by real-time PCR in a set of 77 breast tumour tissues and 17 corresponding normal breast tissues. In breast carcinomas, downregulation of EDN3 expression by FC2 could be detected in 60 of 77 cases (78\%; median: 21-fold) as compared with the normal breast reference standard (Figure 1d). This downregulation was still evident when comparing EDN3 expression among all tumour and normal breast tissues as illustrated by box plot analysis $(P<0.001)$ (Figure 1e) as well as when comparing fold changes of EDN3 expression among the 17 matched pairs (Figure 1f). In the latter analysis, 14 of 17 pairs (82\%) showed EDN3 downregulation by FC2, with a median expression change of 13 -fold.

\section{Differential EDN3 protein expression in human breast cancer}

To analyse whether loss of EDN3 expression in breast cancer is also evident on the protein level, we used a TMA comprising 150 invasive breast carcinomas and 44 normal breast tissue specimens. The specificity of the antibody applied was determined by the simultaneous use of blocking peptide against EDN3 in normal breast samples, which showed a clear decrease of overall EDN3 staining (Additional data file 1). EDN3 protein was clearly detectable in $75.0 \%$ (32 of 44 ) of normal breast tissue samples analysed (Figure 2a, b), as defined by an immunoreactivity score (IRS) of at least 8 . The mean normal expression was determined to be IRS $=8.2( \pm$ 3.8 standard deviations [SDs]). Expression was predominantly localised in luminal and basal epithelial cells of the normal breast and was weakly detectable in normal stromal compartments. In contrast, invasive breast carcinomas showed complete loss or reduced EDN3 expression (IRS < 8) in 45.3\% (68 of 150) of cases (Figure 2c, d) and abundant EDN3 expression in 54.7\% (82 of 159) (Figure 2e, f). Mean EDN3 expression in invasive breast carcinomas was determined to be IRS $=6.7$ ( \pm 4.0 SDs). EDN3 protein was rarely observed in tumour stroma (that is, was detectable only in those stromal cells adjacent to tumour cells with strong EDN3 expression). The difference of EDN3 expression between tumours and normal breast tissues was statistically significant (Mann-Whitney $U$ test: $P=0.037$; Student unpaired $t$ test: $P=0.039$ ).

\section{Loss of EDN3 expression is associated with adverse patient outcome in human breast cancer}

To investigate a potential clinical relevance of EDN3 in breast cancer, we first analysed whether EDN3 protein expression is 


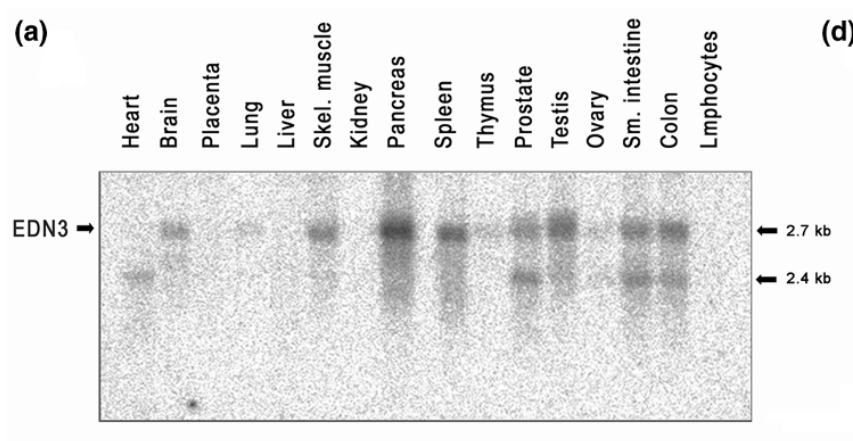

(b)

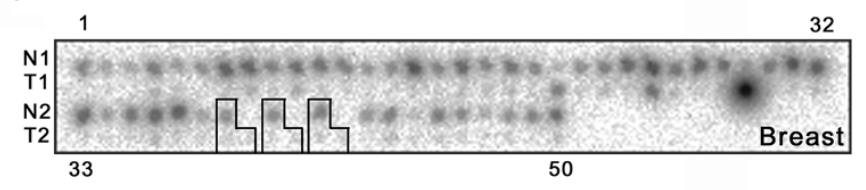

(c)

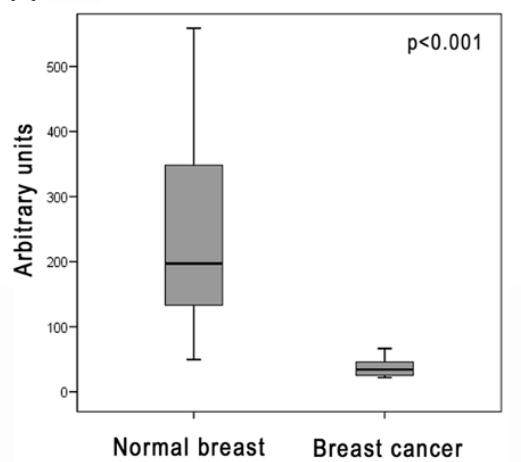

(d)

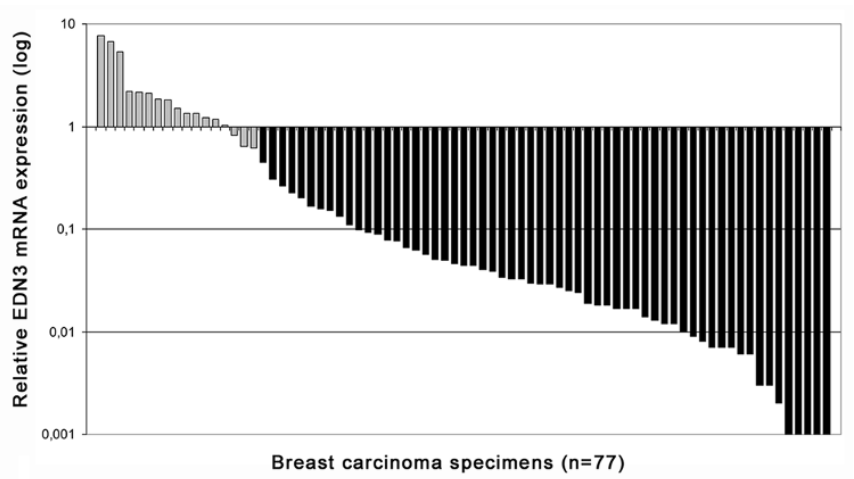

(e)

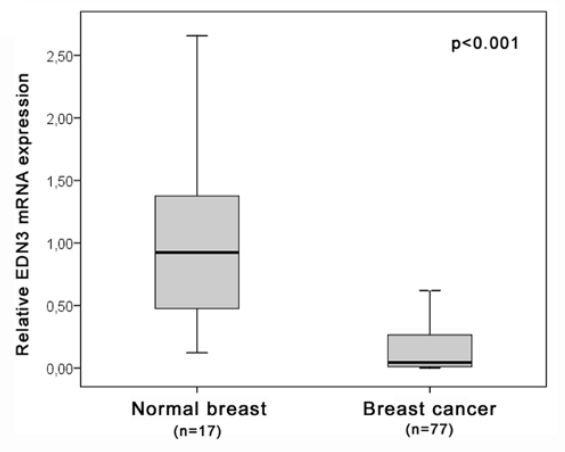

(f)

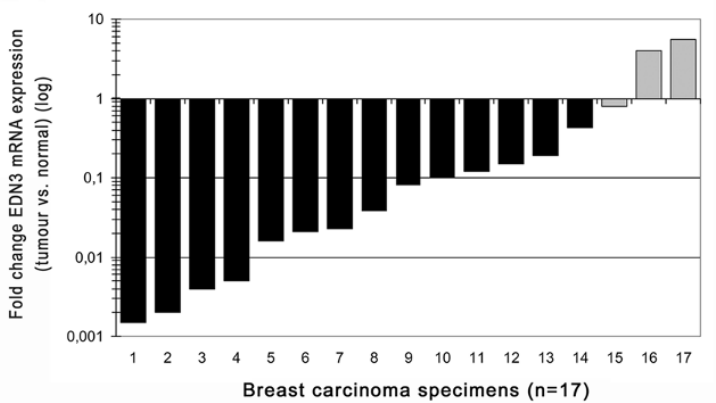

Differential expression of $E D N 3$ mRNA in human breast cancer. (a) A multiple tissue Northern blot hybridised with an EDN3-specific probe indicates ubiquitous expression of EDN3 mRNA in a variety of normal tissue types. In some tissues, both major EDN3 transcript variants are expressed (2.4 and $2.7 \mathrm{~kb}$ ). (b) The same probe was hybridised to a breast cancer array containing cDNA pairs from 50 breast carcinoma tissues (T), 50 matched normal breast tissues $(\mathrm{N})$ and 3 metastatic tissues. The outlined groups represent matched pairs, including the metastatic deposit, and consecutive numbers indicate specimen spots on the array. (c) Box plot demonstrating significant downregulation of EDN3 expression between normal and tumourous breast tissues $(P<0.001$. Student paired $t$ test; extreme value of specimen \#29 omitted). Horizontal lines indicate group medians, and boxes indicate $25 \%$ to $75 \%$ quartiles, range, peak and minimum. (d) Real-time polymerase chain reaction analysis demonstrated loss of $E D N 3$ expression in $78 \%$ of breast carcinomas by FC2 (fold change of greater than 2) (black bars) whilst $22 \%$ showed no deregulation (grey bars). (e) Box plot demonstrating the different distributions of $E D N 3$ expression among normal breast tissues and breast carcinomas $(P<0.001$, Mann-Whitney $U$ test). Horizontal lines indicate group medians, and boxes indicate $25 \%$ to $75 \%$ quartiles, range, peak and minimum. (f) Fold changes of $E D N 3$ expression in 17 matched pairs of normal breast and breast carcinoma samples revealed loss of expression in 13 cases (76\%) and a median expression change of 13-fold. EDN3, endothelin-3.

associated with clinicopathological parameters. In a bivariate analysis, differential EDN3 expression was not associated with patient age at diagnosis, tumour size, lymph node metastasis, histological grade, histological type, tumour focality or oestrogen or progesterone receptor status (Table 4). Interestingly, in a univariate survival analysis, we found a significant association between low EDN3 expression and unfavourable CSS ( $P$
$=0.022$ ) (Figure $2 \mathrm{~g}$ and Table 5). Patients with low EDN3 expression in the tumour had a mean CSS of 99 months (95\% confidence interval [Cl] 85 to 113 months) as compared with patients with tumours showing high EDN3 expression, which had a prolonged mean CSS of 116 months $(95 \% \mathrm{Cl} 106$ to 126 months). The visual impression of the Kaplan-Meier curves suggests also an association of EDN3 expression with 
(a)

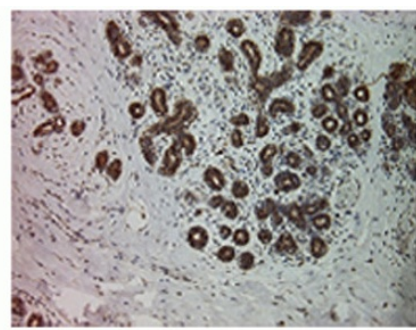

(c)

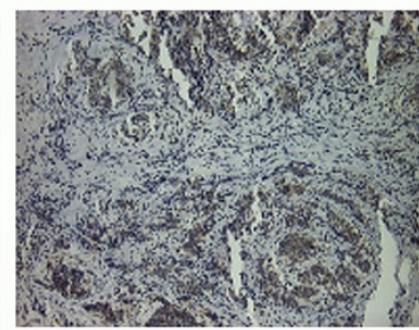

(e)

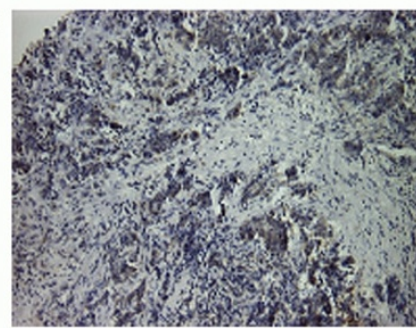

(g)

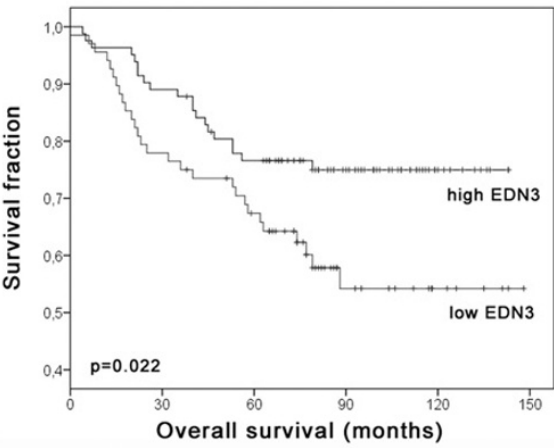

(b)

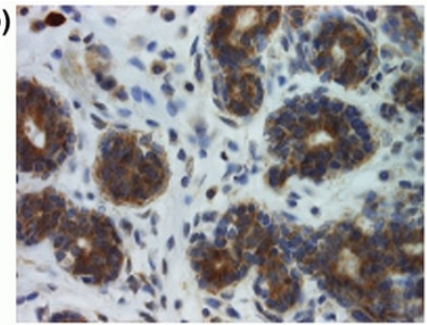

(d)

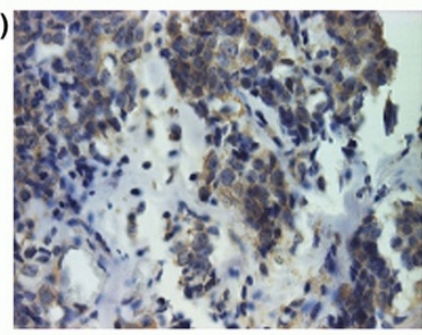

(f)

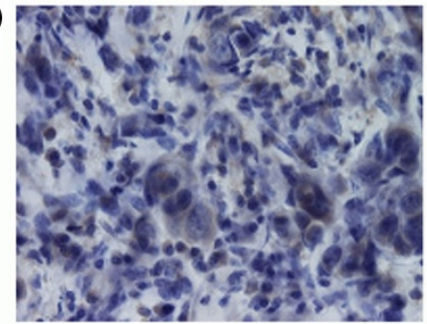

(h)

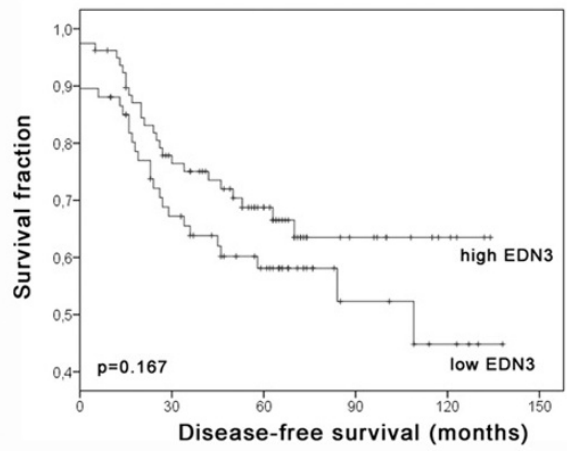

Differential EDN3 protein expression in human breast cancer and its clinical relevance. (a) Abundant EDN3 protein expression in normal breast epithelium. (b) Magnification of specimen shown in (a). (c) Representative invasive-ductal carcinoma showing moderate EDN3 protein expression. (d) Magnification of specimen shown in (c). (e) Representative invasive-ductal carcinoma with substantial loss of EDN3 protein expression. (f) Magnification of specimen shown in (e). Kaplan-Meier curves indicating that retaining high EDN3 protein expression (immunoreactivity score of at least 8 ) in the tumour is significantly associated with more favourable $(\mathbf{g})$ breast cancer-specific survival $(P=0.022$, log-rank test) but not $(\mathrm{h})$ disease-free survival. Magnifications: $\times 100(a, c, e), \times 200(b, d, f)$. EDN3, endothelin-3.

DFS (Figure $2 \mathrm{~h}$ ), but this was statistically not significant $(P=$ 0.167) (Table 5). Next, we performed a multivariate Cox regression analysis to test for independent significance of EDN3 expression as a prognostic factor in patient CSS (Table 6). Patient age at diagnosis, tumour size, lymph node metastasis, histological grade and EDN3 expression were included in the model. After reverse selection, patient age, lymph node status, grade and EDN3 expression remained significant in the Cox model, with low EDN3 expression displaying a twofold elevated risk of dying from breast cancer (hazard ratio 1.98, $95 \% \mathrm{Cl} 1.09$ to $3.61 ; P=0.025)$.

\section{Loss of EDN3 mRNA expression in breast cancer cell lines}

The $\mathrm{NH}_{2}$-terminal peptide structure of EDN3 differs considerably in essential amino acids between residues 2 and residues 4 to 7 from those of EDN1 and EDN2 (Figure 3a). This region bulges out of the basic EDN structure and has been reported to represent a major domain for binding specificity to EDN 
Table 4

Clinicopathological factors in relation to EDN3 protein expression

\begin{tabular}{|c|c|c|c|c|}
\hline \multirow[b]{2}{*}{ Variables } & \multicolumn{4}{|c|}{ EDN3 expression } \\
\hline & Number ${ }^{a}$ & Low $($ IRS < 8) & High $(\mathrm{IRS} \geq 8)$ & $P$ value ${ }^{b}$ \\
\hline \multicolumn{5}{|l|}{ Clinicopathological factors } \\
\hline \multicolumn{5}{|l|}{ Age at diagnosis } \\
\hline$\leq 59$ years & 83 & 36 & 47 & 0.632 \\
\hline$>59$ years & 67 & 32 & 35 & \\
\hline \multicolumn{5}{|l|}{ Tumour size } \\
\hline $\mathrm{pT} 1$ & 48 & 21 & 27 & 0.728 \\
\hline pT2 to pT4 & 100 & 47 & 53 & \\
\hline \multicolumn{5}{|l|}{ Lymph node status ${ }^{c}$} \\
\hline $\mathrm{pNO}$ & 67 & 29 & 38 & 0.742 \\
\hline $\mathrm{pN} 1$ to $\mathrm{pN} 3$ & 80 & 37 & 43 & \\
\hline \multicolumn{5}{|l|}{ Histological grade } \\
\hline G1 and G2 & 83 & 35 & 48 & 0.408 \\
\hline G3 & 66 & 33 & 33 & \\
\hline \multicolumn{5}{|l|}{ Histological type } \\
\hline Ductal & 122 & 53 & 69 & 0.385 \\
\hline Lobular & 12 & 5 & 7 & \\
\hline Other & 16 & 10 & 6 & \\
\hline \multicolumn{5}{|l|}{ Tumour focality } \\
\hline Unifocal & 130 & 61 & 69 & 0.467 \\
\hline Multifocal & 19 & 7 & 12 & \\
\hline \multicolumn{5}{|l|}{ Oestrogen receptor } \\
\hline Negative $(I R S d \leq 2)$ & 38 & 19 & 19 & 0.698 \\
\hline Positive (IRS > 2) & 83 & 45 & 38 & \\
\hline \multicolumn{5}{|l|}{ Progesterone receptor } \\
\hline Negative (IRS $\mathbf{d} \leq 2)$ & 85 & 41 & 44 & 0.704 \\
\hline Positive (IRS > 2) & 40 & 21 & 19 & \\
\hline \multicolumn{5}{|l|}{ Her2 status } \\
\hline Negative (IHC: $0 ; 1+)$ & 105 & 46 & 59 & 0.169 \\
\hline Positive (IHC: $2+; 3+)$ & 23 & 14 & 9 & \\
\hline
\end{tabular}

aOnly female patients with primary invasive breast cancer were included. bFisher exact test (two-sided). ${ }^{\circ}$ According to the UICC (Union Internationale contre le Cancer): TNM Classification of Malignant Tumours [19].dImmunoreactivity score (IRS) according to Remmele and Stegner [24]. EDN3, endothelin-3; IHC, immunohistochemistry.

receptors and thus is critical in EDN signalling activity [29]. Because we found that EDN3 expression is frequently lost in breast cancer tissues, we next compared EDN1, EDN2 and EDN3 mRNA expression in breast cell lines in parallel. EDN1 was much more strongly expressed in all cancerous cell lines (MCF7, SKBR3, MDA-MB231 and BT20) than in non-cancerous MCF12A cells (Figure $3 b$ ), showing a mean upregulation of 13.9-fold ( \pm 7.8 SDs). EDN2 was more strongly expressed in SKBR3 cells but less expressed in MCF7, MDA-MB231 and BT20 as compared with MCF12A cells. EDN3 expression, however, was clearly downregulated in all cancerous cell lines as compared with non-cancerous cells, revealing a mean expression of 0.008 ( \pm 0.009 SDs) of that found in MCF12A cells (set to 1). Therefore, upregulation of EDN1 appears to 
Table 5

Clinicopathological factors in relation to disease-free and breast cancer-specific survival

\begin{tabular}{|c|c|c|c|c|c|c|}
\hline & \multicolumn{3}{|c|}{ Disease-free survival } & \multicolumn{3}{|c|}{ Breast cancer-specific survival } \\
\hline & Number ${ }^{\mathrm{a}}$ & Events & $P$ value ${ }^{b}$ & Number ${ }^{\mathrm{a}}$ & Events & $P$ value ${ }^{b}$ \\
\hline \multicolumn{7}{|l|}{ Variables } \\
\hline \multicolumn{7}{|l|}{ Clinicopathological factors } \\
\hline \multicolumn{7}{|l|}{ Age at diagnosis } \\
\hline$\leq 59$ years & 83 & 28 & 0.163 & 83 & 19 & $0.005^{c}$ \\
\hline$>59$ years & 63 & 25 & & 67 & 29 & \\
\hline \multicolumn{7}{|l|}{ Tumour sized } \\
\hline pT1 & 47 & 11 & $0.007^{c}$ & 48 & 9 & $0.013^{c}$ \\
\hline pT2 to pT4 & 97 & 42 & & 100 & 39 & \\
\hline \multicolumn{7}{|l|}{ Lymph node status ${ }^{d}$} \\
\hline $\mathrm{pNO}$ & 67 & 9 & $<0.001^{c}$ & 67 & 10 & $<0.001^{c}$ \\
\hline $\mathrm{pN} 1$ to $\mathrm{pN} 3$ & 76 & 41 & & 80 & 35 & \\
\hline \multicolumn{7}{|l|}{ Histological grade } \\
\hline $\mathrm{G} 1$ and $\mathrm{G} 2$ & 81 & 23 & $0.008^{c}$ & 83 & 19 & $0.002^{c}$ \\
\hline G3 & 64 & 30 & & 66 & 29 & \\
\hline \multicolumn{7}{|l|}{ Histological type } \\
\hline Ductal & 120 & 46 & 0.376 & 122 & 40 & 0.474 \\
\hline Lobular & 11 & 4 & & 12 & 5 & \\
\hline Other & 15 & 3 & & 16 & 3 & \\
\hline \multicolumn{7}{|l|}{ Tumour focality } \\
\hline Unifocal & 127 & 44 & 0.158 & 130 & 39 & 0.082 \\
\hline Multifocal & 18 & 9 & & 19 & 9 & \\
\hline \multicolumn{7}{|l|}{ Oestrogen receptor } \\
\hline Negative $($ IRSe $\leq 2)$ & 38 & 16 & 0.351 & 38 & 16 & 0.101 \\
\hline Positive (IRS > 2) & 79 & 25 & & 83 & 22 & \\
\hline \multicolumn{7}{|l|}{ Progesterone receptor } \\
\hline Negative (IRSe $\leq 2)$ & 81 & 32 & 0.214 & 85 & 32 & 0.056 \\
\hline Positive (IRS > 2) & 40 & 11 & & 40 & 8 & \\
\hline \multicolumn{7}{|l|}{ Her2 status } \\
\hline Negative (IHC: $0 ; 1+)$ & 101 & 38 & 0.840 & 105 & 33 & 0.445 \\
\hline Positive (IHC: $2+; 3+)$ & 23 & 9 & & 23 & 9 & \\
\hline \multicolumn{7}{|l|}{ EDN3 expression } \\
\hline Low $($ IRSe < 8) & 67 & 28 & 0.167 & 68 & 28 & $0.022^{c}$ \\
\hline High (IRS $\geq 8$ ) & 79 & 25 & & 82 & 20 & \\
\hline
\end{tabular}

aOnly female patients with primary invasive breast cancer were included. bLog-rank test. cSignificant data. dAccording to the UICC (Union Internationale contre le Cancer): TNM Classification of Malignant Tumours [19].elmmunoreactivity score (IRS) according to Remmele and

Stegner [24]. EDN3, endothelin-3; IHC, immunohistochemistry. 
Multivariate Cox regression analysis of clinicopathological factors potentially influencing breast cancer-specific survival, including EDN3 protein expression

\begin{tabular}{|c|c|c|c|c|c|}
\hline \multirow[t]{2}{*}{ Variable } & \multirow[t]{2}{*}{ Value } & \multirow[t]{2}{*}{$P$ value } & \multirow[t]{2}{*}{ Hazard ratio (HR) } & \multicolumn{2}{|c|}{ 95\% confidence interval of HR } \\
\hline & & & & Lower & Upper \\
\hline \multicolumn{6}{|l|}{ Age } \\
\hline Continuous & & $0.005^{a}$ & $1.04^{\mathrm{a}}$ & $1.01^{\mathrm{a}}$ & $1.06^{a}$ \\
\hline \multicolumn{6}{|l|}{ pT } \\
\hline pT1 & 0 & & 1.00 & & \\
\hline pT2 to pT4 & 1 & 0.109 & 1.87 & 0.87 & 4.04 \\
\hline \multicolumn{6}{|l|}{$\mathrm{pN}$} \\
\hline pNO & 0 & & 1.00 & & \\
\hline $\mathrm{pN} 1$ to $\mathrm{pN} 3$ & 1 & $0.002^{a}$ & $3.12^{a}$ & $1.53^{a}$ & $6.33^{a}$ \\
\hline \multicolumn{6}{|l|}{ Grade } \\
\hline G1 and G2 & 0 & & 1.00 & & \\
\hline G3 & 1 & $0.013^{a}$ & $2.17^{a}$ & $1.18^{\mathrm{a}}$ & $3.99^{a}$ \\
\hline \multicolumn{6}{|c|}{ EDN3 expression } \\
\hline High & 0 & & 1.00 & & \\
\hline Low & 1 & $0.025^{a}$ & $1.98^{\mathrm{a}}$ & $1.09 \mathrm{a}$ & $3.61^{a}$ \\
\hline
\end{tabular}

The variables were categorised according to Tables 4 and 5, except for age (continuous). aSignificant data. EDN3, endothelin-3.

coincide with downregulation of EDN3 in breast cancer cell lines.

\section{Methylation of the EDN3 promoter in breast cancer cell lines}

Since promoter hypermethylation is responsible for transcriptional silencing of important tumour suppressor genes in various human cancer types [30], we searched all three EDN genes for the presence of $\mathrm{CpG}$ islands in their promoter region. A region of high $\mathrm{CpG}$ density in the EDN3 nucleotide sequence was identified as a $\mathrm{CpG}$ island (Figure 4a), whereas the $\mathrm{CpG}$ density in EDN1 and EDN2 is lower and does not define a $\mathrm{CpG}$ island under the selected criteria. To analyse the methylation status of the EDN3 CpG promoter (Figure 4b), we performed MSP with DNA after bisulphite treatment from nonmalignant human tissues and three non-malignant and four malignant breast cell lines. The utilised MSP primers were tested on a dilution series of poly-methylated DNA, which revealed a sensitivity of $0.01(1 \%)$ in detecting methylated EDN3 DNA molecules in a background of unmethylated EDN3 DNA molecules (Figure 4c). We observed no methylation of the EDN3 promoter in HMEC cells, human placental tissue, peripheral blood lymphocytes (Figure 4c) or non-malignant MCF10A cells (Figure 4e). A weak methylation signal was detected in non-malignant MCF12A cells. Of the malignant breast cell lines, MDA-MB231 and MCF7 harboured a methylated EDN3 promoter. In BT20 cells, both unmethylated and methylated EDN3 promoter sequences could be detected, whereas EDN3 was unmethylated in SKBR3 cells. Next, we analysed the association between EDN3 expression and promoter methylation in six breast cell lines by in vitro demethylating their DNA and assessing EDN3 mRNA expression after the treatment. A clear conversion of methylation could be observed in cell lines that were originally methylated in the EDN3 promoter region (that is, in MDA-MB231 and MCF7 cells) (Figure 4e), resulting in 47-fold and 28-fold increases, respectively, in EDN3 mRNA expression (Figure 4f). In BT20 cells, however, the demethylating effect was weaker and led to a 3-fold induction of EDN3 transcription. In weakly methylated MCF12A cells, the conversion of methylated alleles induced EDN3 expression by 5 -fold, whereas no substantially altered change of EDN3 expression could be detected in unmethylated MCF10A (1.6-fold) or SKBR3 (1.0-fold) cells.

\section{Frequent EDN3 promoter methylation in primary breast carcinomas}

Next, we analysed EDN3 promoter methylation in primary breast cancer as well. In total, 89 of 128 breast carcinoma samples (69.5\%) showed EDN3 promoter methylation (for example, \#5 in Figure 5a). The remaining breast carcinoma samples (39 of $128 ; 30.5 \%$ ) were not affected by this epigenetic modification (for example, \#13 in Figure 5b). None of the 17 normal breast tissues exhibited EDN3 promoter methylation. Cancerous tissues yielded a PCR product with primers specific for the unmethylated EDN3 promoter sequence in all cases, due to non-malignant contaminants (stromal cells and 
Figure 3

(b)
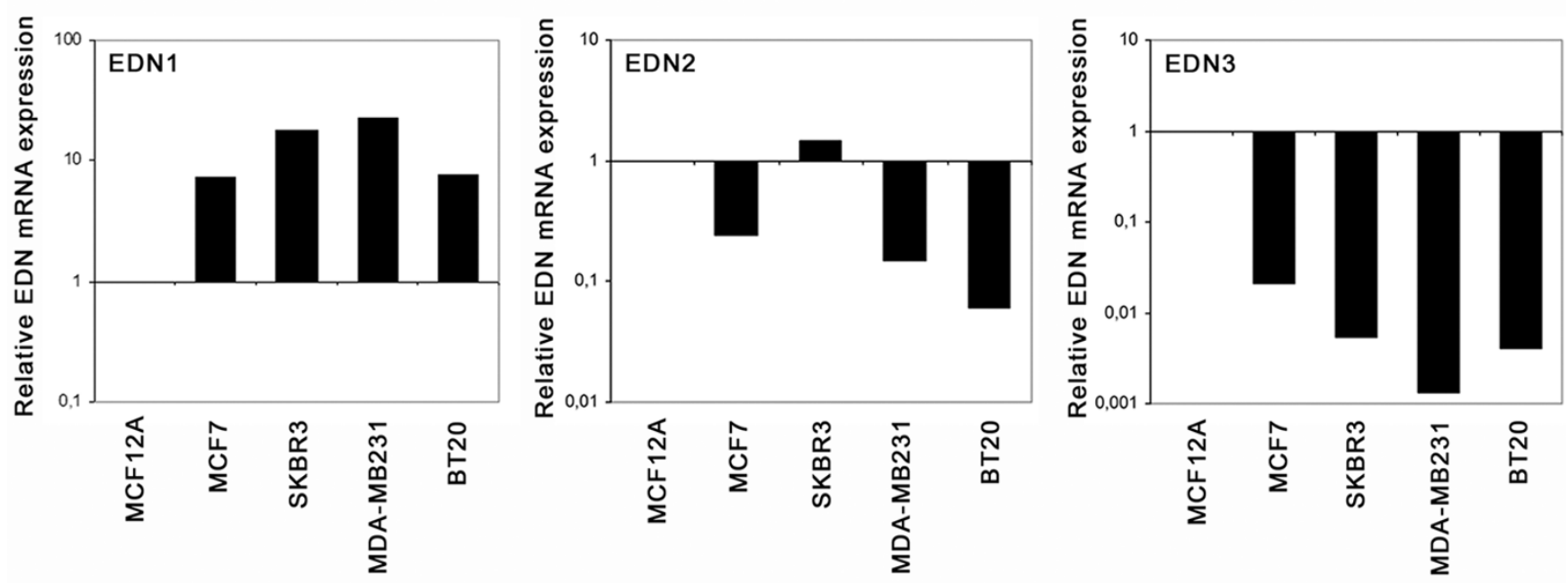

Endothelin (EDN) mRNA expression analysis in breast cell lines. (a) Alignment of the primary amino acid (aa) structure of human EDN1, EDN2 and EDN3 after post-translational cleavage to the biologically active 21-aa form [4]. The secondary structure consists of single $\alpha$-helices containing two disulphide bonds that hold them in a conical spiral shape, joining cysteins at positions 1-15 and 3-11 [53]. EDN3 structure differs mainly in the $\mathrm{NH}_{2}$-terminal region from the structure of EDN1 and EDN2. This region forms a bulge out of the basic EDN structure and has been reported to represent a major domain for binding specificity to EDN receptors and thus is critical in endothelin signalling activity [29]. Numbers indicate consecutive aa residues, and aa residues are indicated in universal single-letter aa code. (b) Real-time polymerase chain reaction comparing EDN3 expression with EDN1 and EDN2 expression. While EDN1 is overexpressed in cancerous breast cell lines (MCF7, SKBR3, MDA-MB231 and BT20), EDN3 expression is abrogated in the same malignant cells as compared with MCF12A cells (set to 1 in each diagram).

endothelial cells) present in the bulk tumour tissue, as has also been described by Suzuki and colleagues [31].

We next aimed to analyse whether EDN3 promoter methylation was associated with EDN3 mRNA expression in these tissues. For 71 breast cancer specimens, both EDN3 methylation and EDN3 mRNA expression have been investigated in parallel. Figure $5 \mathrm{~b}$ shows the distribution of EDN3 mRNA expression among these two groups. While carcinoma samples with unmethylated EDN3 promoter exhibited similar EDN3 mRNA expression as compared with normal breast tissues (Figure 1e), breast carcinomas with EDN3 methylation exhibited a significant downregulation of EDN3 mRNA expression as compared with EDN3 unmethylated samples $(P=$ 0.005 , Mann-Whitney $U$ test).
Finally, we asked whether EDN3 promoter methylation may be of clinical relevance in human breast cancer, as we have previously found for EDN3 protein expression. In a univariate analysis, the EDN3 methylation status in breast carcinomas was not associated with patient age at diagnosis, tumour size, lymph node metastasis, histological grade, histological type or oestrogen or progesterone receptor positivity (Table 7). In contrast to EDN3 protein expression, EDN3 promoter methylation was significantly associated neither with patient CSS ( $P$ $=0.703)$ nor with patient DFS $(P=0.632)$ (data not shown).

\section{Discussion}

The involvement of EDNs in tumourigenesis has been described in several reports $[4,10,15]$. In contrast to the potentially oncogenic role of EDN1 and EDN2, there is still little knowledge about the role of EDN3 in cancer initiation or progression. A recent study demonstrated abundant expres- 
Figure 4
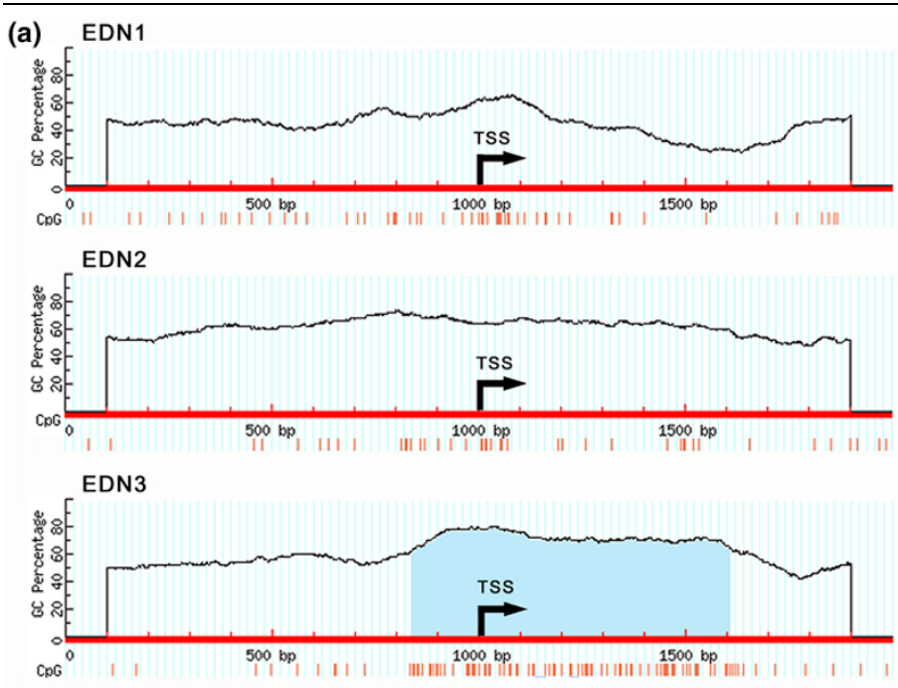

(b)

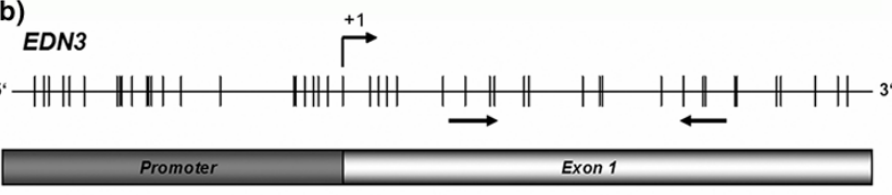

(e)
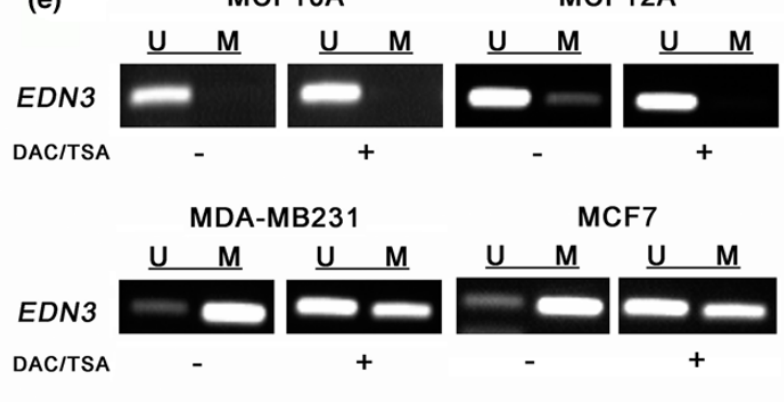

\section{MCF7}
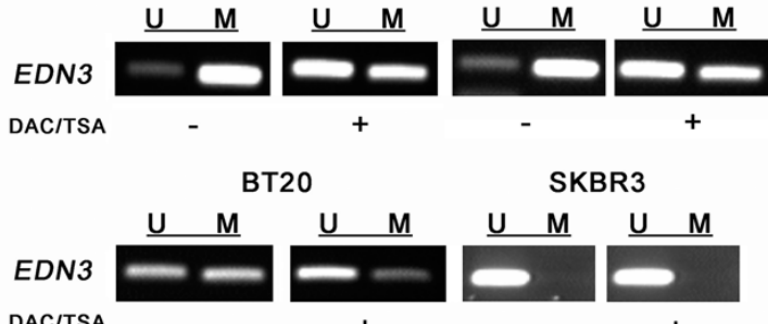

SKBR3

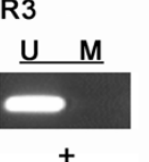

(c)

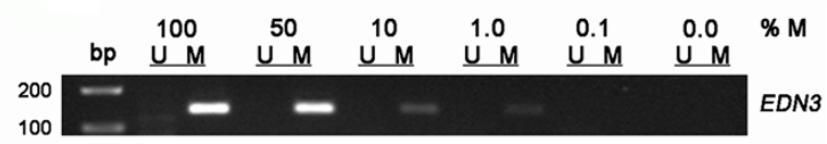

(d)

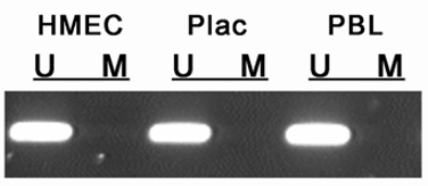

(f)

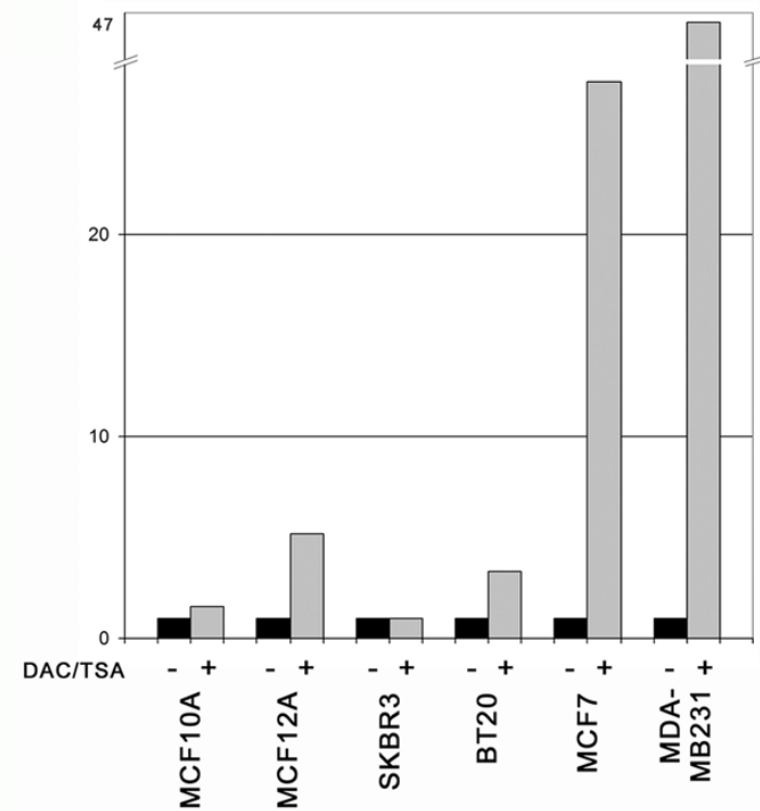

EDN3 promoter methylation analysis in breast cell lines. (a) Prediction of CpG islands in EDN family genes. A 2-kb genomic nucleotide sequence of $E D N 1, E D N 2$ and $E D N 3$ was analysed with MethPrimer software [25]. A region of particularly high CpG density (red vertical bars) in the EDN3 nucleotide sequence proximal to the transcription start site (TSS) was identified as a CpG island (blue shaded). (b) Schematic representation of the $E D N 3$ gene fragment that has been analysed for methylation. Arrows indicate hybridisation sites of methylation-specific polymerase chain reaction (MSP) primers, +1 indicates TSS, and vertical bars depict CpG dicnucleotides. (c) A dilution series of in vitro poly-methylated DNA with unmethylated DNA demonstrates the sensitivity of the applied MSP primers, which detect at least $1 \%$ of methylated DNA (M) in a background of unmethylated DNA in MSPs. (d) The EDN3 promoter is unmethylated in HMEC and non-malignant tissues. (e) EDN3 methylation analysis in breast cancer cell lines before $(-)$ and after $(+)$ treatment with demethylating (DAC) and histone reacetylating (TSA) drugs. In cell lines originally showing methylated EDN3 promoter alleles (MCF12A, MDA-MB231, MCF7 and BT20), a conversion of methylation was achieved as indicated by a gain of signal strength for non-methylation $(\mathrm{U})$ and loss of signal strength for methylation $(\mathrm{M})$, whereas in originally unmethylated cells (MCF10A and SKBR3), the treatment showed no effect. (f) EDN3 mRNA expression analysis as determined by real-time polymerase chain reaction before (-) and after $(+)$ the demethylating treatment illustrates strong re-expression in those cell lines that were substantially demethylated (MCF7: 28-fold; MDA-MB231: 47fold) as compared with cell lines showing weaker demethylation (BT20: 3-fold; MCF12A: 5-fold) or unmethylated cells (MCF10A: 1.6-fold; SKBR3: 1.0-fold). bp, base pairs; CpG, cytosine-phosphate-guanine dinucleotide; DAC, 5-aza-2'-deoxycytidine; EDN, endothelin; GC, guanine-cytosine content; HMEC, human mammary epithelial cells; PBL, peripheral blood lymphocyte; Plac, placental tissue; TSA, trichostatin A. 


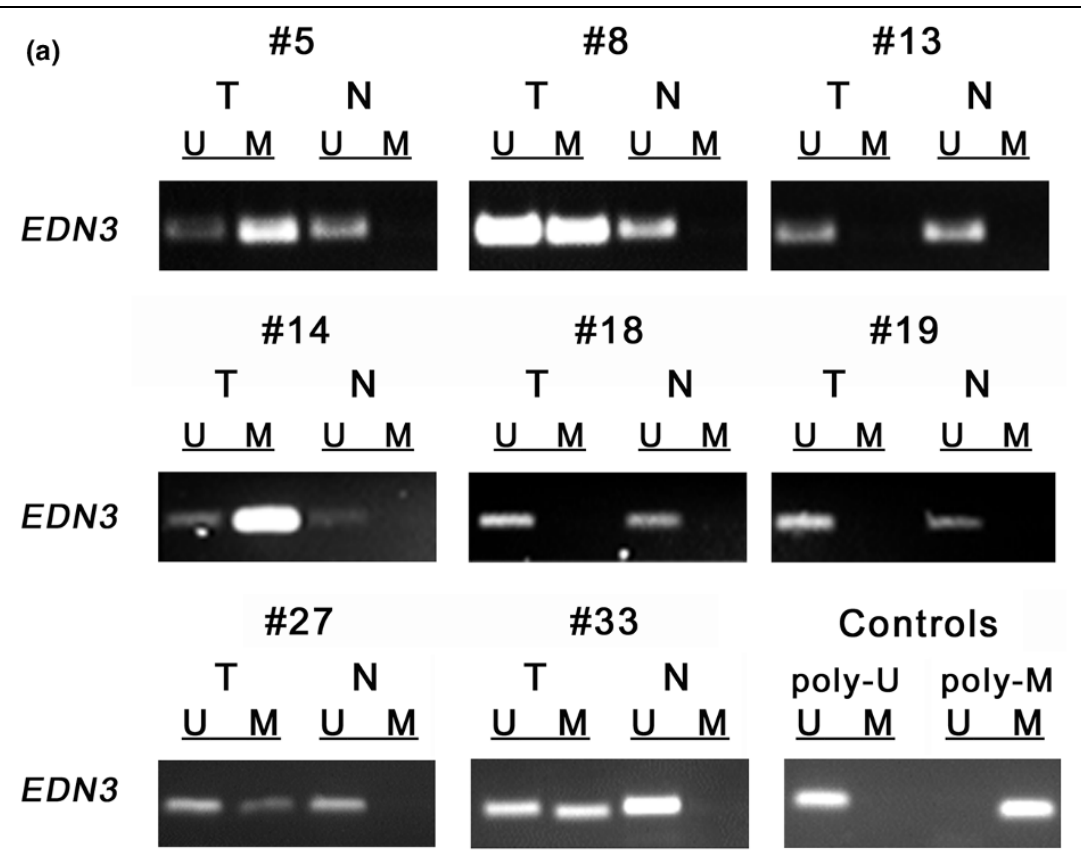

(b)

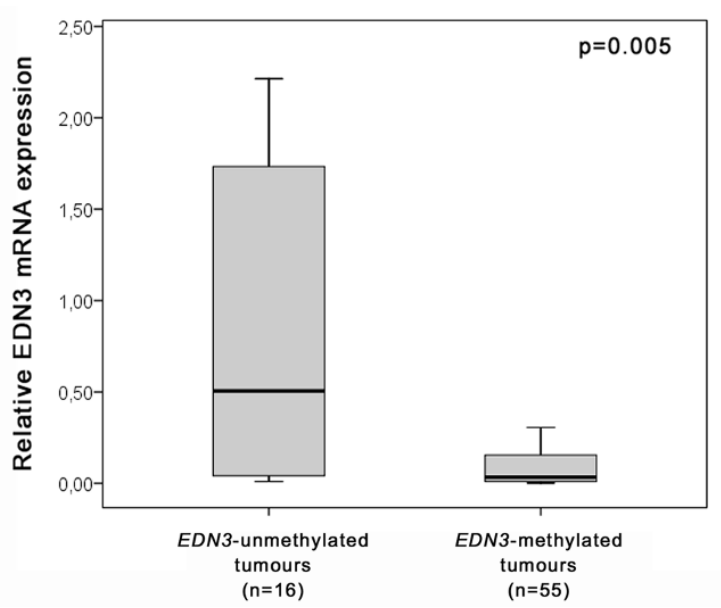

EDN3 promoter methylation in primary breast cancer. (a) Methylation-specific polymerase chain reaction (MSP) was performed on bisulphite-treated DNA from breast carcinomas $(T)$ and matching normal breast tissue $(N)$. Representative MSP results from eight patients are shown. MSP controls were commercially available poly-unmethylated (poly-U) or in vitro poly-methylated (poly-M) DNA. (b) Box plot demonstrating the significant association between EDN3 promoter methylation and EDN3 mRNA expression in these tissues. For 71 samples, EDN3 expression has been assessed in parallel to $E D N 3$ promoter methylation. EDN3-methylated tumours show significant downregulation as compared with EDN3-unmethylated tumours $(P=0.005$, Mann-Whitney $U$ test). Horizontal lines indicate group medians, and boxes indicate $25 \%$ to $75 \%$ quartiles, range, peak and minimum. EDN3, endothelin-3; M, methylated; $U$, unmethylated.

sion of EDN1 and EDN2 but complete absence of EDN3 expression in a representative set of human breast cancer cell lines [12]. Because we have previously found that EDN3 mRNA expression is downregulated in primary breast carcinomas as compared with normal breast tissues [27,28], we aimed in this report to provide the first comprehensive analysis of EDN3 expression and its potential implication in human breast cancer.
Initially, we screened various non-malignant epithelial tissues for EDN3 mRNA expression and also analysed its expression using a breast cancer cDNA dot blot array. Besides abundant expression in several human tissues, EDN3 was strongly expressed in normal breast samples, providing evidence for a functional role in epithelial tissues such as the mammary gland. In contrast, most matched breast carcinomas showed diminished EDN3 mRNA expression both on the cDNA dot blot 
Table 7

Clinicopathological parameters in relation to EDN3 promoter methylation

\begin{tabular}{|c|c|c|c|c|}
\hline \multirow[t]{2}{*}{ Variables } & \multicolumn{4}{|c|}{ EDN3 promoter } \\
\hline & Number ${ }^{a}$ & Unmethylated (percentage) & Methylated (percentage) & $P$ value ${ }^{b}$ \\
\hline Total & 128 & $39(30.5)$ & $89(69.5)$ & \\
\hline \multicolumn{5}{|l|}{ Clinicopathological factors } \\
\hline \multicolumn{5}{|l|}{ Age at diagnosis } \\
\hline$\leq 59$ years & 64 & $22(34)$ & $42(66)$ & 0.443 \\
\hline$>59$ years & 64 & $17(29)$ & $47(71)$ & \\
\hline \multicolumn{5}{|l|}{ Tumour size ${ }^{\mathrm{c}}$} \\
\hline pT1 & 44 & $15(34)$ & $29(66)$ & 0.680 \\
\hline pT2 to pT4 & 72 & $21(29)$ & $51(71)$ & \\
\hline \multicolumn{5}{|l|}{ Lymph node status ${ }^{c}$} \\
\hline pNO & 57 & $16(28)$ & $41(72)$ & 0.676 \\
\hline $\mathrm{pN} 1$ to $\mathrm{pN} 3$ & 51 & $17(33)$ & $34(67)$ & \\
\hline \multicolumn{5}{|l|}{ Histological grade } \\
\hline G1 and $\mathrm{G} 2$ & 68 & $18(26)$ & $50(74)$ & 0.310 \\
\hline G3 & 49 & $18(37)$ & $31(63)$ & \\
\hline \multicolumn{5}{|l|}{ Histological type } \\
\hline Ductal & 103 & $32(31)$ & $71(69)$ & 0.849 \\
\hline Lobular & 15 & $5(33)$ & $10(67)$ & \\
\hline Other & 6 & $1(17)$ & $5(83)$ & \\
\hline \multicolumn{5}{|l|}{ Immunohistochemistry } \\
\hline \multicolumn{5}{|l|}{ Oestrogen receptor } \\
\hline Negative $\left(\operatorname{IRS}^{\mathrm{d}} \leq 2\right)$ & 33 & $11(33)$ & $22(67)$ & 0.655 \\
\hline Positive (IRS > 2) & 85 & $24(28)$ & $61(72)$ & \\
\hline \multicolumn{5}{|l|}{ Progesterone receptor } \\
\hline Negative (IRS $\mathbf{d} \leq 2)$ & 33 & 11 (33) & $22(67)$ & 0.655 \\
\hline Positive (IRS > 2) & 85 & $24(28)$ & $61(72)$ & \\
\hline
\end{tabular}

aOnly female patients with primary invasive breast cancer were included. bFisher exact test (two-sided). ${ }^{\circ}$ According to the UICC (Union Internationale contre le Cancer): TNM Classification of Malignant Tumours [19]. dImmunoreactivity score (IRS) according to Remmele and Stegner [24]. EDN3, endothelin-3.

array and by real-time PCR analysis. This finding supports the current evidence that EDN3 may exert a functional role divergent to that of EDN1/EDN2 in the human mammary gland [18]. A further TMA analysis revealed that EDN3 protein is abundantly expressed in normal breast whereas its expression is reduced in a large fraction of breast carcinomas. Frequency differences may arise due to the use of different techniques (real-time PCR versus IHC) on separate tumour cohorts (fresh frozen versus FFPE) and accomplishing different scoring systems. Loss of EDN3 protein expression was not associated with relevant clinicopathological factors. For instance, it occurred with almost equal frequency among all tumour sizes (pT1 to pT4), suggesting that it may be an early event in the development of infiltrating breast carcinoma. Since EDN3 is thought to counterbalance the effects mediated by EDN1 and EDN2 [4,18], we propose that loss of EDN3 expression could actively enhance overexpression of the ET-axis. Recently, upregulation of ET-axis members was found to be associated with higher histological grade, lymph node metastasis and lymphovascular invasion in breast cancer [5] and also with advanced tumour progression in ovarian cancer [32], prostate cancer [33], Ewing sarcoma and neuroblastoma [11]. A systematic expression analysis on larger breast carcinoma cohorts and metastatic deposits is now required, including all three EDNs and EDNRA/EDNRB. This will unravel in detail the inter-relationship between EDN3 expression loss and upregu- 
lation of EDN1/2 and EDNRA/B as well as its association with breast tumour progression. In our study, loss of EDN3 expression was associated with adverse patient outcome. So far, overexpressions of EDN1 and EDNRA were already reported as being associated with impaired survival in breast cancer $[5,34]$. Our findings support the view that an imbalanced ETaxis is of pivotal relevance in breast cancer biology and that EDN3, unlike other members of the ET-axis, may represent a novel tumour suppressor gene in the human mammary gland.

Addressing the molecular cause by which EDN3 expression becomes abrogated, we found that the EDN3 gene promoter, unlike $E D N 1$ and $E D N 2$, contains a $\mathrm{CpG}$ island as a potential substrate to aberrant hypermethylation and consequently gene inactivation. Indeed, we detected EDN3 promoter methylation in cancerous breast cell lines in functional association with loss of EDN3 mRNA expression. Moreover, a hypermethylated EDN3 promoter was also detected in $70 \%$ of breast carcinoma specimens in significant association with loss of EDN3 expression. We therefore conclude that aberrant EDN3 methylation is a tumour-specific event and the predominant mechanism leading to EDN3 expression loss in breast cancer. However, it remains elusive why patient survival was not associated with EDN3 methylation as it was with loss of EDN3 protein expression. In fact, only very few studies detected such outcome association on both molecular levels (for example, for SFRP1 [22,35] or ITIH5 [36]), probably due to considerable sensitivity differences of the available detection techniques as well as further genetic or epigenetic alterations contributing to the loss of a gene's expression. Interestingly, EDNRB was previously described to be methylated in numerous tumour entities, such as lung, colon, prostate, bladder, kidney, liver, oesophageal, nasopharyngeal cancer and leukemia [37-45], but to the authors' knowledge, never in gynaecological tumours. So far, there has been no evidence that EDNRB becomes methylated in breast carcinomas since a previous study demonstrated strong EDNRB expression in all invasive ductal carcinoma samples and in all analysed cancerous breast cell lines [4]. Notably, an ET-axis expression pattern similar to that of breast cancer was recently found in cervical cancer; that is, upregulation of EDN1, EDN2, EDNRA and EDNRB expression was accompanied by downregulation of EDN3 expression in cancerous cervix as compared with normal cervical epithelium [46]. This suggests that a decrease of EDN3 expression accompanied by an increase of EDNRB expression may be a particular feature of gynaecological tumour entities.

Since the ET-axis represents crucial decisive elements for the direction of tumour growth, invasion and neo-angiogenesis, it provides a promising intervention point for molecular targeted therapies. EDNR antagonists have been proven as potent and specific ET-axis inhibitors that block cellular pathways implicated in tumour growth. The drug bosentan, which targets both EDNRA and EDNRB, inhibits tumour growth, vascularisa- tion and bone metastasis in breast cancer [47]. Atrasenatan, targeting EDNRA, is capable of inhibiting proliferation and cancer growth-promoting processes $[48,49]$. In addition, blockers of EDNRA resensitised cancer cells to paclitaxelinduced apoptosis, as observed in ovarian, prostatic, cervical and nasopharyngeal cancer cell lines [49-51] as well as in primary ovarian and breast cancer [5,52]. Our study adds a novel aspect to therapeutically targeting the ET-axis in breast cancer. Since the epigenetic lock of the EDN3 gene is potentially reversible by DNA methyltransferase (DNMT) or histone acetyltransferase (HDAC) inhibitors or both, these drug classes may provide a future option in a combined treatment consisting of a decrease in EDN1/2 signalling by blocking EDNRs together with the reactivation of EDN3 expression by DNMT and HDAC inhibitors. Apparently, molecular rebalancing of the ET-axis in cancerous cells may be most efficiently achieved by targeting all deregulated axis molecules.

\section{Conclusions}

In summary, our study contributes to the understanding of deregulated EDN signalling commonly observed in human tumours. EDN3 expression, in contrast to abundant EDN1 and EDN2 expression, becomes frequently inactivated by promoter methylation in human breast cancer, potentially causing aberrant activation of the ET-axis, which in turn may promote this disease. We therefore conclude that EDN3 may be an interesting future target for an epigenetic therapy. Forced EDN3 re-expression by DNA demethylation agents in conjunction with inhibitors of EDNRs may rebalance ET-axis-mediated cellular signalling to a more normal status, thus having a therapeutic impact in human breast cancer.

\section{Competing interests}

The authors declare that they have no competing interests.

\section{Authors' contributions}

FW participated in the conception and design of the study and carried out the gene expression analyses, immunohistochemical studies and methylation experiments. JV performed statistical evaluations, participated in data interpretation and wrote the manuscript. OG provided expertise in DNA methylation analysis and critically revised the manuscript. $\mathrm{AH}$ provided clinical samples and clinicopathological data, performed data interpretation and critically revised the manuscript. ME participated in data interpretation and critically revised the manuscript. RK participated in the design and coordination of the study and critically revised the manuscript. ED planned and coordinated the study and critically revised the manuscript. All authors read and approved the final manuscript. 


\section{Additional files}

The following Additional files are available online:

\section{Additional data file 1}

A PDF file that demonstrates the specificity of the applied EDN3 antibody by use of competitive blocking peptide in immunohistochemistry.

See http://www.biomedcentral.com/content/ supplementary/bcr2319-S1.pdf

\section{Acknowledgements}

The excellent technical assistance from Sonja von Serényi, Sevim Alkaya and Inge Losen is greatly appreciated. We thank Dieter Niederacher (Heinrich-Heine University, Düsseldorf, Germany) and Matthias Dürst (Friedrich-Schiller University, Jena, Germany) for kindly providing patient samples. We thank Monika Klinkhammer-Schalke and Felicitas Horn (Tumour Registry, Regensburg, Germany) for continuous help in obtaining clinical patient information and follow-up data. Immunohistochemical scoring was kindly performed by Nuran Bektas (Institute of Pathology, University Hospital of the RWTH, Aachen, Germany). HMEC DNA was a generous gift by Bernhard Lüscher (Institute of Biochemistry, University Hospital of the RWTH, Aachen, Germany). This work is a research project within the German Human Genome Project and was supported by a grant from the Bundesministerium für Bildung und Forschung (BMBF) to ED (01KW040-1).

\section{References}

1. Grimshaw MJ: Endothelins and hypoxia-inducible factor in cancer. Endocr Relat Cancer 2007, 14:233-244.

2. Levin ER: Endothelins. N Engl J Med 1995, 333:356-363.

3. Masaki T: The endothelin family: an overview. J Cardiovasc Pharmacol 2000, 35:S3-S5.

4. Grimshaw MJ, Hagemann T, Ayhan A, Gillet CE, Binder C, Balkwill FR: A role for endothelin-2 and its receptors in breast tumor cell invasion. Cancer Res 2004, 64:2461-2468.

5. Smollich M, Wulfing P: The endothelin axis: a novel target for pharmacotherapy of female malignancies. Curr Vasc Pharmacol 2007, 5:239-248.

6. Pollock DM, Keith TL, Highsmith RF: Endothelin receptors and calcium signaling. FASEB J 1995, 9:1196-1204.

7. Bagnato $A$, Catt $\mathrm{KJ}$ : Endothelin as autocrine regulators of tumor cell growth. Trends Endocrinol Metab 1998, 9:378-383.

8. Bagnato A, Spinella F, Rosano L: Emerging role of the endothelin axis in ovarian tumour progression. Endocr Relat Cancer 2005, 12:761-772.

9. Pla P, Larue L: Involvement of endothelin receptors in normal and pathological development of neural crest cells. Int J Dev Biol 2003, 47:315-325.

10. Alanen K, Deng DX, Chakrabarti S: Augmented expression of endothelin-1, endothelin-3 and the endothelin-B receptor in breast carcinoma. Histopathology 2000, 36:161-167.

11. Berry $P$, Burchill $S$ : Endothelins may modulate invasion and proliferation of Ewing's sarcoma and neuroblastoma. Clin Sci (Lond) 2002, 103(Suppl 48):322S-326S.

12. Grimshaw MJ: Endothelins in breast tumour cell invasion. Cancer Lett 2005, 222:129-138.

13. Bagnato A, Natali PG: Endothelin receptors as novel targets in tumor therapy. J Transl Med 2004, 2:16.

14. Spinella F, Rosano L, Di Castro V, Natali PG, Bagnato A: Endothelin-1 induces vascular endothelial growth factor by increasing hypoxia-inducible factor-1alpha in ovarian carcinoma cells. $J$ Biol Chem 2002, 277:27850-27855.
15. Nelson JB, Chan-Tack K, Hedican SP, Magnuson SR, Opgenorth TJ, Bova GS, Simons JW: Endothelin-1 production and decreased endothelin $B$ receptor expression in advanced prostate cancer. Cancer Res 1996, 56:663-668.

16. Hagemann T, Binder C, Binder L, Pukrop T, Trümper L, Grimshaw $\mathrm{MJ}$ : Expression of endothelins and their receptors promotes an invasive phenotype of breast tumor cells but is insufficient to induce invasion in benign cells. DNA Cell Biol 2005 , 24:766-776.

17. Mitaka C, Hirata Y, Ichikawa K, Yokoyama K, Emori T: Effects of TNF-alpha on hemodynamic changes and circulating endothelium-derived vasoactive factors in dogs. Am J Physiol 1994, 267: $\mathrm{H} 1530-\mathrm{H} 1536$.

18. Thomson E, Kumarathasan $P$, Vincent R: Pulmonary expression of preproET-1 and preproET-3 mRNAs is altered re ciprocally in rats after inhalation of air pollutants. Exp Biol Med (Maywood) 2006, 231:979-984.

19. TNM Classification of Malignant Tumours 6th edition. Edited by: Sobin LH, Wittekind C. New York: Wiley-Liss; 2002.

20. Elston EW, Ellis IO: Method for grading breast cancer. J Clin Pathol 1993, 46:189-190.

21. Bubendorf L, Nocito A, Moch H, Sauter G: Tissue microarray (TMA) technology: miniaturized pathology archives for highthroughput in situ studies. J Patho/ 2001, 195:72-79.

22. Veeck J, Niederacher D, An H, Klopocki E, Wiesmann F, Betz B, Galm O, Camara O, Dürst M, Kristiansen G, Huszka C, Knüchel R, Dahl E: Aberrant methylation of the Wnt antagonist SFRP1 in breast cancer is associated with unfavourable prognosis. Oncogene 2006, 25:3479-3488.

23. Fink L, Seeger W, Ermert L, Hänze J, Stahl U, Grimminger F, Kummer W, Bohle RM: Real-time quantitative RT-PCR after laserassisted cell picking. Nat Med 1998, 4:1329-1333.

24. Remmele W, Stegner HE: Recommendation for uniform definition of an immunoreactive score (IRS) for immunohistochemical estrogen receptor detection (ER-ICA) in breast cancer tissue. Pathologe 1987, 8:138-140.

25. Li LC, Dahiya R: MethPrimer: designing primers for methylation PCRs. Bioinformatics 2002, 18:1427-1431.

26. Herman JG, Graff JR, Myöhänen S, Nelkin BD, Baylin SB: Methylation-specific PCR: a novel PCR assay for methylation status of CpG islands. Proc Natl Acad Sci USA 1996, 93:9821-9826.

27. Dahl E, Sadr-Nabavi A, Klopocki E, Betz B, Grube S, Kreutzfeld R, Himmelfarb M, Gelling S, Klaman I, Hinzmann B, Kristiansen G, Grützmann R, Kuner R, Petschke B, Rhiem K, Wiechen K, Sers C, Wiestler O, Schneider A, Höfler H, Nährig J, Dietel M, Schäfer R, Rosenthal A, Schmutzler R, Dürst M, Meindl A, Niederacher D: Systematic identification and molecular characterization of genes differentially expressed in breast and ovarian cancer. $J$ Pathol 2005, 205:21-28.

28. Dahl E, Kristiansen G, Gottlob K, Klaman I, Ebner E, Hinzmann B, Hermann K, Pilarsky C, Dürst M, Klinkhammer-Schalke M, Blaszyk $H$, Knuechel R, Hartmann A, Rosenthal A, Wild PJ: Molecular profiling of laser-microdissected matched tumor and normal breast tissue identifies karyopherin alpha2 as a potential novel prognostic marker in breast cancer. Clin Cancer Res 2006, 12:3950-3960.

29. Wallace BA, Janes RW, Bassolino DA, Krystek SR Jr: A comparison of X-ray and NMR structures for human endothelin-1. Protein Sci 1995, 4:75-83.

30. Esteller M: Epigenetic gene silencing in cancer: the DNA hypermethylome. Hum Mol Genet 2007, 16 (Spec No 1):R50-59.

31. Suzuki H, Watkins DN, Jair KW, Schuebel KE, Markowitz SD, Chen WD, Pretlow TP, Yang B, Akiyama Y, Van Engeland M, Toyota M, Tokino T, Hinoda Y, Imai K, Herman JG, Baylin SB: Epigenetic inactivation of SFRP genes allows constitutive WNT signaling in colorectal cancer. Nat Genet 2004, 36:417-422.

32. Donninger $\mathrm{H}$, Bonome $\mathrm{T}$, Radonovich $\mathrm{M}$, Pise-Masison CA, Brady $\mathrm{J}$, Shih $\mathrm{JH}$, Barrett JC, Birrer MJ: Whole genome expression profiling of advance stage papillary serous ovarian cancer reveals activated pathways. Oncogene 2004, 23:8065-8077.

33. Kopetz ES, Nelson JB, Carducci MA: Endothelin-1 as a target for therapeutic intervention. Invest New Drugs 2002, 20:173-182.

34. Wulfing $P$, Diallo R, Kersting C, Wülfing C, Poremba C, Rody A, Greb RR, Böcker W, Kiesel L: Expression of endothelin-1, endothelin-A, and endothelin-B receptor in human breast cancer and correlation with long-term follow-up. Clin Cancer Res 2003, 9:4125-4131. 
35. Klopocki E, Kristiansen G, Wild PJ, Klaman I, Castanos-Velez E, Singer G, Stöhr R, Simon R, Sauter G, Leibiger H, Essers L, Weber B, Hermann K, Rosenthal A, Hartmann A, Dahl E: Loss of SFRP1 is associated with breast cancer progression and poor prognosis in early stage tumors. Int J Onco/ 2004, 25:641-649.

36. Veeck J, Chorovicer M, Naami A, Breuer E, Zafrakas M, Bektas N, Dürst M, Kristiansen G, Wild PJ, Hartmann A, Knuechel R, Dahl E: The extracellular matrix protein ITIH5 is a novel prognostic marker in invasive node-negative breast cancer and its aberrant expression is caused by promoter hypermethylation. Oncogene 2008, 27:865-875.

37. Chen SC, Lin CY, Chen YH, Fang HY, Cheng CY, Chang CW, Chen RA, Tai HL, Lee CH, Chou MC, Lin TS, Hsu LS: Aberrant promoter methylation of EDNRB in lung cancer in Taiwan. Oncol Rep 2006, 15:167-172.

38. Pao MM, Tsutsumi M, Liang G, Uzvolgyi E, Gonzales FA, Jones PA: The endothelin receptor $B$ (EDNRB) promoter displays heterogeneous, site specific methylation patterns in normal and tumor cells. Hum Mol Genet 2001, 10:903-910.

39. De Marzo AM, Isaacs WB, Nelson WG: Hypermethylation of $\mathrm{CpG}$ islands in primary and metastatic human prostate cancer. Cancer Res 2004, 64:1975-1986.

40. Friedrich MG, Weisenberger DJ, Cheng JC, Chandrasoma S, Siegmund KD, Gonzalgo ML, Toma MI, Huland H, Yoo C, Tsai YC, Nichols PW, Bochner BH, Jones PA, Liang G: Detection of methylated apoptosis-associated genes in urine sediments of bladder cancer patients. Clin Cancer Res 2004, 10:7457-7465.

41. Pflug BR, Zheng H, Udan MS, D'Antonio JM, Marshall FF, Brooks JD, Nelson JB: Endothelin-1 promotes cell survival in renal cell carcinoma through the ET(A) receptor. Cancer Lett 2007, 246:139-148.

42. Hsu LS, Lee HC, Chau GY, Yin PH, Chi CW, Lui WY: Aberrant methylation of EDNRB and p16 genes in hepatocellular carcinoma (HCC) in Taiwan. Oncol Rep 2006, 15:507-511.

43. Zhao BJ, Sun DG, Zhang M, Tan SN, Ma X: Identification of aberrant promoter methylation of EDNRB gene in esophageal squamous cell carcinoma. Dis Esophagus 2009, 22:55-61.

44. Lo KW, Tsang YS, Kwong J, To KF, Teo PM, Huang DP: Promoter hypermethylation of the EDNRB gene in nasopharyngeal carcinoma. Int J Cancer 2002, 98:651-655.

45. Hsiao PC, Liu MC, Chen LM, Tsai CY, Wang YT, Chen J, Hsu LS: Promoter methylation of p16 and EDNRB gene in leukemia patients in Taiwan. Chin J Physiol 2008, 51:27-31.

46. Sun de J, Liu Y, Lu DC, Kim W, Lee JH, Maynard J, Deisseroth A: Endothelin-3 growth factor levels decreased in cervical cancer compared with normal cervical epithelial cells. Hum Pathol 2007, 38:1047-1056.

47. Dréau D, Karaa A, Culberson C, Wyan H, McKillop IH, Clemens MG: Bosentan inhibits tumor vascularization and bone metastasis in an immunocompetent skin-fold chamber model of breast carcinoma cell metastasis. Clin Exp Metastasis 2006, 23:41-53.

48. Nelson J, Bagnato A, Battistini B, Nisen P: The endothelin axis: emerging role in cancer. Nat Rev Cancer 2003, 3:110-116.

49. Rosanò L, Di Castro V, Spinella F, Nicotra MR, Natali PG, Bagnato $A$ : ZD4054, a specific antagonist of the endothelin A receptor, inhibits tumor growth and enhances paclitaxel activity in human ovarian carcinoma in vitro and in vivo. Mol Cancer Ther 2007, 6:2003-2011.

50. Bagnato A, Cirilli A, Salani D, Simeone P, Muller A, Nicotra MR, Natali PG, Venuti A: Growth inhibition of cervix carcinoma cells in vivo by endothelin A receptor blockade. Cancer Res 2002, 62:6381-6384.

51. Akhavan A, McHugh KH, Guruli G, Bies RR, Zamboni WC, Strychor SA, Nelson JB, Pflug BR: Endothelin receptor A blockade enhances taxane effects in prostate cancer. Neoplasia 2006, 8:725-732.

52. Jazaeri AA, Awtrey CS, Chandramouli GV, Chuang YE, Khan J, Sotiriou C, Aprelikova O, Yee CJ, Zorn KK, Birrer MJ, Barrett JC, Boyd J: Gene expression profiles associated with response to chemotherapy in epithelial ovarian cancers. Clin Cancer Res 2005, 11:6300-6310.

53. Ortega Mateo A, De Artiñano AA: Highlights on endothelins: a review. Pharmacol Res 1997, 36:339-351. 